\title{
Research on Shaanxi Han Dynasty Stone Sports Entertainment Regional Characteristics
}

\author{
Yong Liu \\ Department of Physical Education, Yulin University, Yulin, 719000
}

Keywords: Shaanxi, The Han Dynasty, Stone, Sports Entertainment Culture, Regional Characteristics

\begin{abstract}
In shanbei region is the eastern Han Dynasty stone art on one of the main areas of distribution, its unique geographical location social background has provided favorable conditions for the stone production, through the northern Shaanxi sports entertainment s, unearthed in Han Dynasty stone distribution and regional characteristics, kinds of sports culture in the Han Dynasty stone, for the modern interpretation of the Han Dynasty Shaanxi sports entertainment culture activities provide valuable basis.
\end{abstract}

\section{Introduction}

Han Dynasty stone, Wang Jianzhong in the "Han Dynasty Stone" is defined as: "Han Dynasty stone is the Chinese Han Dynasty, decorated in the tomb, tomb, grave and other buildings to stone to the ground, or painted with ink lines, painted with a special color of painting works of art. "It is the ancient Chinese funeral customs services for a unique form of art, with a strong national color, regional characteristics and characteristics of the times, is the most popular in the Han Dynasty society a cultural ritual, but also the most elite at the time of a material and spiritual products, it is the treasure house of our precious heritage. As a typical cultural relic of the Han Dynasty, Han painting is of great value to the study of the Han Dynasty culture and the ancient Chinese civilization.

\section{The Division of the Age of Northern Shaanxi Yulin City Han Dynasty Portrait Stone}

Northern Shaanxi Yulin area, the Han Dynasty belongs to the county and the West River County, under the jurisdiction of the state. Since the first year of the Yuan Dynasty (89 years) Dou Xian big break the Northern Huns, to restore control of northern Shaanxi jurisdiction, to the beginning of two years (108 years) constitution invasion of northern Shaanxi, the control of the Eastern Han Dynasty began to weaken in northern Shaanxi Four years (129 years) Shun Emperor to restore control of northern Shaanxi jurisdiction, to Yonghe five years (140 years) Qiang people invaded the county and the West River County, the two counties were forced to move to the stone, during this period "on the county" The region's agriculture and animal husbandry development to a higher level, people praised the region "fertile wild thousands of miles, grain Jia Yin plot", "water plants rich, soil should be animal husbandry, cattle and horses tail, sheep lane." The development of social economy in northern Shaanxi provides the necessary material guarantee for the production of the stone tiles, which is an important period for the development of the mountainous scenery in northern Shaanxi for more than 100 years.

\section{The Main Unearthed Distribution of the Northern Shaanxi Han Dynasty Portrait}

Northern Shaanxi now refers to the Yulin City, Yan'an City, but the Han Dynasty Han Dynasty portrait stone so far Yan'an area has not yet unearthed only Yulin area unearthed a large number of Han Dynasty stone. Northern Shaanxi is one of the four regions of Han Dynasty's portrait stone distribution. So far, there are 954 stone statues unearthed in Yulin city. The main locations are as 
follows:

The main unearthed distribution of the Han Dynasty in northern Shaanxi (Table 1)

\begin{tabular}{|c|c|c|c|}
\hline $\begin{array}{l}\text { County } \\
\text { (district) }\end{array}$ & Location, Time & Save place & Quantity \\
\hline Suide County & $\begin{array}{l}\text { Yanjia Cha, Huang Jiatai, forty Li shop, Wuli } \\
\text { shop, Zhang Jiabeng, Liu Jia Wan „, Wu Yaoquan, } \\
\text { Chengguan Town Xishan Temple, Pei home hilly, } \\
\text { Zhao shop, party ditch, Yi He Home Bay, road } \\
\text { ditch, after thinking home ditch, Cuijiagou, Su Ji } \\
\text { Ge Tuo, Zhaishan village, Haojiagou }\end{array}$ & $\begin{array}{l}\text { Shaanxi Han Shi } \\
\text { Museum, Shaanxi } \\
\text { Beilin Museum, } \\
\text { Suide Han Shi } \\
\text { Exhibition Hall, } \\
\text { Yulin Han Dynasty } \\
\text { Stone Museum }\end{array}$ & 540 \\
\hline $\begin{array}{l}\text { Mizhi } \\
\text { County }\end{array}$ & $\begin{array}{l}\text { Guanzhuang, town of Bay, Sun Jiagou, party } \\
\text { ditch, Zhang Xing Zhuang }\end{array}$ & Suide Museum、 & 220 \\
\hline $\begin{array}{l}\text { Shenmu } \\
\text { County }\end{array}$ & Big castle, Liu Xiangcun & Shenmuwenguan & 84 \\
\hline $\begin{array}{l}\text { Yuyang } \\
\text { District }\end{array}$ & Ancient city beach & $\begin{array}{l}\text { Yulin Han Dynasty } \\
\text { Stone Museum }\end{array}$ & 47 \\
\hline $\begin{array}{l}\text { Qingjian } \\
\text { County }\end{array}$ & Hejiawan, fold home Ping & $\begin{array}{l}\text { Qing Jian County } \\
\text { Council will }\end{array}$ & 30 \\
\hline $\begin{array}{l}\text { Zizhou } \\
\text { County }\end{array}$ & Huaihua Bay, Miaojiaping & $\begin{array}{ll}\text { Zizhou } & \text { County } \\
\text { Council } & \end{array}$ & 17 \\
\hline $\begin{array}{l}\text { Wubao } \\
\text { County }\end{array}$ & Li Jiayuan & $\begin{array}{l}\text { Yulin Han stone } \\
\text { museum }\end{array}$ & 7 \\
\hline $\begin{array}{l}\text { Jingbian } \\
\text { County }\end{array}$ & Zhaishan & $\begin{array}{l}\text { Yulin Han stone } \\
\text { museum }\end{array}$ & 5 \\
\hline $\begin{array}{l}\text { Yokoyama } \\
\text { County }\end{array}$ & Yokoyama Prefecture & $\begin{array}{l}\text { Yulin Han stone } \\
\text { museum }\end{array}$ & 4 \\
\hline
\end{tabular}

\section{The Regional Characteristics of Northern Shaanxi Han Dynasty Portrait Stone Leisure Sports}

There are many kinds of recreational and recreational sports activities in the Han Dynasty in the Han Dynasty. The content is rich in form and the regional characteristics are obvious. Northern Shaanxi portrait stone leisure sports and entertainment types Cuju, tame beast, bucket of beasts, long sleeves dance, build inspiration, discraising, fighting skills, jump pill, fire and so on.

In the four years, the whole picture was divided into four divisions, of which the second lattice was engraved with Fig himself (Fig. Footsteps, three balls placed in the middle, the left side of a hand with the kicker move the referee. The process of entertainment reflects the stability of the social development of the Han Dynasty, people living more comfortable, sports has become an important way for people to a leisure and entertainment. In 1996 in the Shenmu Dabao when the Han tomb unearthed statue map (Figure 3), Wang Chong "Lun Heng" Day: "so ten years of cattle, for the animal husbandry vertical drive; a long beginning of the elephant, Hooked ... ... "that the Western Han Dynasty palace has been tasted elephant entertainment, and steel hook tame in the Eastern Han Dynasty has been recorded, the elephant may belong to the dance as a dance, performances for the nobility, official, watch fun are for the purpose of entertainment, that is, through their own physical movement of the performance skills, so that the audience to meet the needs of spiritual enjoyment; Cuju, Bo Arts and so on are self-entertainment, mainly through physical exercise to meet the physical enjoyment and need.

In March 1957 in northern Shaanxi Suide Sujia Ge Tuo Tomb unearthed a portrait of stone, carved a treadmill dance map (Figure 4,6). Right side of the screen downstairs there is a man and a woman in the step-by-step dance, next to a person standing in the viewing and music. These dance activities as now in northern Shaanxi to keep the waist drum, Yangge activities. Through these has been the disappearance of recreational activities, you can see the Han Dynasty entertainment sports venues and ornamental sports characteristics. 
Leisure Sports Entertainment (Table 2)

\begin{tabular}{|c|c|c|c|}
\hline Species & Project Description & Place of unearthed & Feature \\
\hline Cuju & $\begin{array}{lcc}2 \text { people, } 5 \mathrm{Ju} & 2 \\
\text { hammer drums; } & 2 \\
\text { people, } 20 \mathrm{Ju} & 2 \\
\text { hammer drums; } & 2 \\
\text { people, } 2 & \text { Ju drums } & \\
\end{array}$ & $\begin{array}{l}\text { Suide } \quad \text { County; } \\
\text { Shenmu; }\end{array}$ & $\begin{array}{l}\text { To drums Cuju as the center, } \\
\text { more Ju configuration, held in } \\
\text { the outdoors }\end{array}$ \\
\hline Tame beast & $\begin{array}{l}\text { People tiger fight, } \\
\text { tame elephant, } \\
\text { bullfighting, } \\
\text { cockfighting }\end{array}$ & $\begin{array}{l}\text { Suide forty shop, } \\
\text { Liaodong prefect Han } \\
\text { Tomb; Shou Shenmu } \\
\text { big Paul when the } \\
\text { tomb of stone }\end{array}$ & $\begin{array}{l}\text { The beast scene with grassland } \\
\text { national characteristics. }\end{array}$ \\
\hline A hundred dance & $\begin{array}{l}\text { Build encouragement, } \\
\text { drums, long sleeves } \\
\text { dance, gorgeous } \\
\text { dance; pills, jujitsu, } \\
\text { inverted }\end{array}$ & $\begin{array}{l}\text { Suide County } \\
\text { Cha, Tianjia } \\
\text { grave; forty shop, } \\
\text { Suide Yang Meng } \\
\text { Yuan tomb; Mizi } \\
\text { Xi'an Guanzhuang } \\
\text { Han tomb; Shenmu } \\
\text { Dabao when the Han } \\
\text { Dynasty tomb stone }\end{array}$ & $\begin{array}{l}\text { The combination of opera and } \\
\text { dance in northern Shaanxi, both } \\
\text { entertainment and ornamental, } \\
\text { but also have the function of } \\
\text { martial arts fitness, while } \\
\text { northern Shaanxi is located in } \\
\text { the frontier, embodies the } \\
\text { multi-ethnic sports and } \\
\text { entertainment projects in this } \\
\text { assembly and then spread to the } \\
\text { mainland characteristics. }\end{array}$ \\
\hline
\end{tabular}

Northern Han Dynasty Han Dynasty portrait stone leisure sports activities, many activities are the Han Dynasty to carry out body sculpting, improve physical function common sports activities. (Figure 4) the third grid, reflecting the martial arts activities; long-sleeved dance, gifted dance, pills, jujitsu, inverted and other activities is in the Suide forty pavement stone lintel is very clear (Figure 7) The One of the long sleeves dance is a traditional dance in China, because it is characterized by waving long sleeves and waist movements. This dance mostly for the body of light women's performance, the Han Dynasty Fu Yi "dance Fu": "body such as swimming dragon, sleeves like neon." It is a vivid description of this dance.

(Figure 8), you can clearly see the cast pot of the scene: the two relative to sit, in the pot, the staff of a chopsticks, pots inside the pot There are three chopsticks, put a wine bottle. Vote pot gambling is very real. Six Bo, and for Lu Bo, six books, is a kind of ancient chess game, "Songs of the South": "There are six books." We are in the Suide County forty miles of unearthed statue stone tomb left in the second group (Figure 9) the second group, is the six Bo scene.

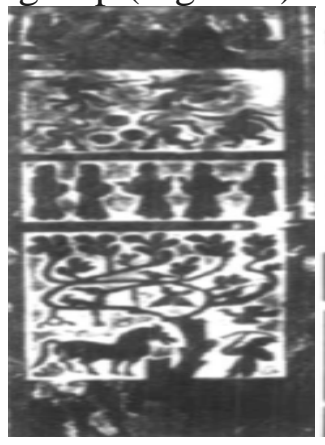

Fig.1

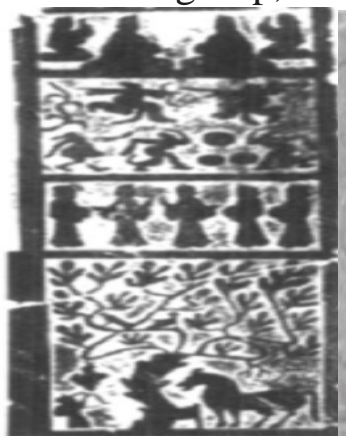

Fig.2

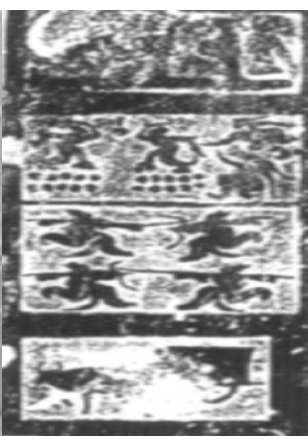

Fig.4

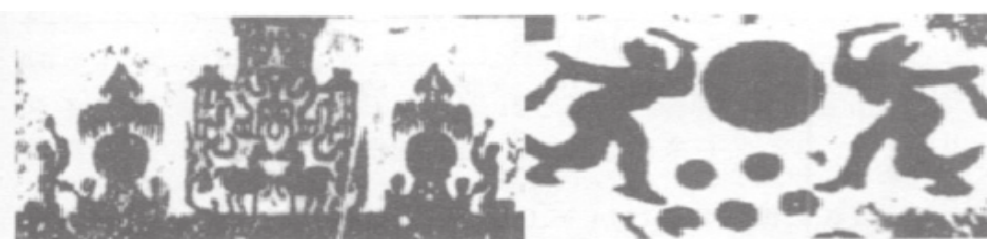

Fig.5 


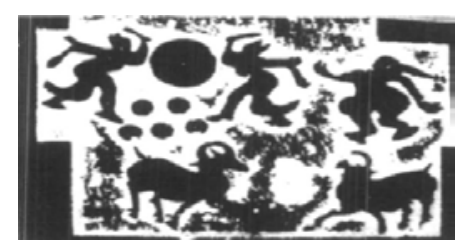

Fig.6

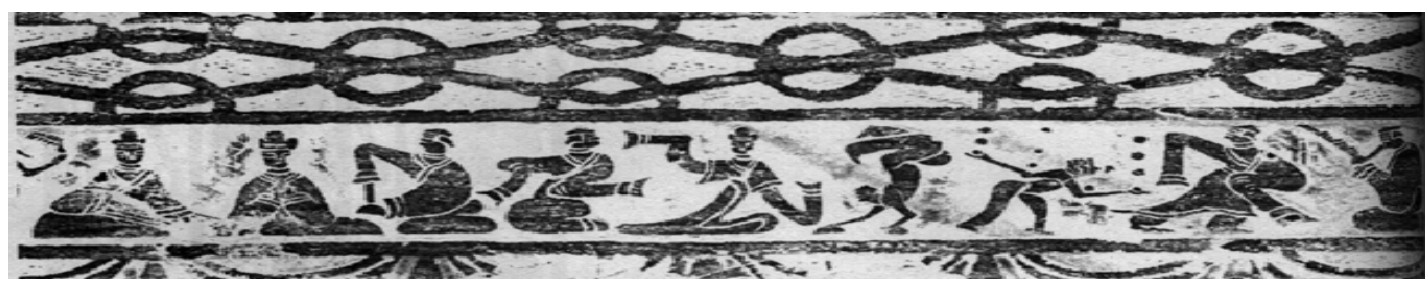

Fig.7

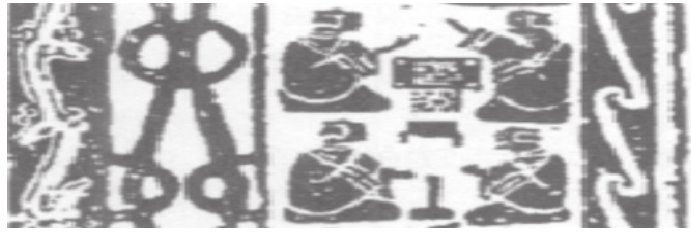

Fig.8

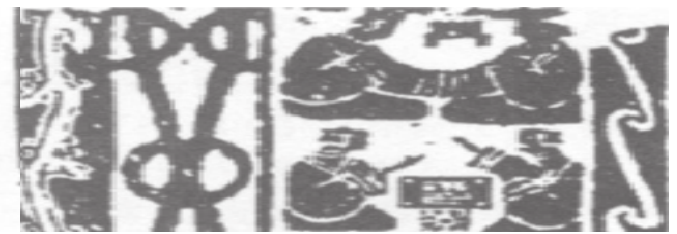

Fig.9

\section{Conclusion}

The characteristics of leisure sports in the Han Dynasty in the northern part of Shaanxi are rich and extensive, reflecting the regional characteristics of the economic, sports and cultural prosperity of the Han Dynasty in northern Shaanxi, and the integration of the frontier culture, national exchange and sports activities in northern Shaanxi. With the development of our society, economy, culture and sports, the statues of northern Han Dynasty have been excavated and protected, and the Han Dynasty Stone Painting Museum in northern Shaanxi has been built, and thousands of precious Han Dynasty stone statues have been preserved. The development of ancient sports activities provides an intuitive platform, through the exhibition of the development of Chinese painting stone tourism, you can promote the understanding of ancient Chinese sports culture and inspire modern people to participate in sports activities.

\section{Acknowledgements}

Fund Project: 2017Shaanxi Province Sports Bureau research projects: number (17129)

\section{References}

[1] Li Lin, Kang Lanying Zhao Liguang. Northern shaanxi han dynasty stone [M]. Xi 'an: shanxi people's publishing house, 1995.

[2] The shaanxi provincial institute of archaeology institute of cultural relics management committee office of yulin city. Shenmufo big insurance when - han dynasty and burial archaeological report [M]. Beijing: science press, 2001.

[3] Lin Boyuan, China sports (part - the days of the ancient) [M]. Beijing. Beijing sports university press, 1987.

[4] Yongliu, Northern shaanxi han stone sports activities analysis, [J] sports cultural Tribune, 2010, 9 (118-127), 